\title{
Quercetin Protects Against Acetaminophen-Induced Acute Nephrotoxicity Associated with the Inhibition of Biomarkers of Acute Kidney Injury in Rats
}

\author{
La Quercetina Protege Contra la Nefrotoxicidad Aguda Inducida por Acetaminofén \\ Asociada con la Inhibición de Biomarcadores de Lesión Renal Aguda en Ratas
}

Nervana M. Bayoumy

BAYOUMY, N. M. Quercetin protects against acetaminophen-induced acute nephrotoxicity associated with the inhibition of biomarkers of acute kidney injury in rats. Int. J. Morphol., 38(4):876-881, 2020.

SUMMARY: Acetaminophen (also called paracetamol, or APAP) causes acute kidney injury after accidental or intentional ingestion of a toxic dose of the drug. We tested whether the antioxidant and anti-inflammatory agent, quercetin (QUR) given alone can protect against acute nephrotoxicity induced by APAP overdose in a rat model of APAP-induced acute kidney injury. Rats were either given a single dose of APAP $(2 \mathrm{~g} / \mathrm{kg})$ before being sacrificed after 24 hours or were pre-treated for 7 days with QUR $(50 \mathrm{mg} / \mathrm{kg})$ before being given a single dose of APAP and then sacrificed 24 hours post APAP ingestion. Kidneys were examined by light microscopy after staining with hematoxylin and eosin (H\&E) and collected blood samples were assayed for biomarkers of oxidative stress, inflammation, and kidney injury. H\&E stained sections of kidney from the model group of rats (APAP) showed substantial damage to the kidney architecture as demonstrated by widening of Bowman's space, tubular dilatation, vacuolization of tubular epithelium, and congested dilated blood vessels, which were partially protected by QUR. In addition, APAP significantly ( $\mathrm{p}<0.05)$ increased blood levels of urea, creatinine, malondialdehyde (MDA), tumor necrosis factor-alpha (TNF-a), and interleukin-6 (IL-6), which were significantly $(\mathrm{p}<0.05)$ reduced by QUR. These results indicate that quercetin partially protects against APAP-induced acute kidney injury in rats, which is associated with the inhibition of biomarkers of oxidative stress and inflammation and kidney injury.

KEY WORDS: Acute nephrotoxicity; Acetaminophen; Quercetin; Rat model.

\section{INTRODUCTION}

Hepato-nephrotoxicity is common in both humans and experimental animal models after the ingestion of an overdose of the analgesic and antipyretic drug, acetaminophen (APAP) (McGill et al., 2012; Karaali et al., 2018). APAP is the most common agent of intentional self-harm and APAP poisoning claimed the life of 284 persons aged 12 years and over between 1993-1996 in England and Wales, UK (Hawton et al., 2004). In addition, APAP poisoning represents about $50 \%$ of acute liver failure admitted cases in the United States of America (Ostapowicz et al., 2002; Larson et al., 2005). APAP is metabolized in the liver and hepatotoxic metabolites that represent about $10 \%$ of the whole metabolites are rapidly inactivated by glutathione (GSH) to protect the hepatocytes (James et al., 2003). But, with the drug overdose for example, the elevated levels of liver toxic metabolites, mainly $\mathrm{N}$-acetylp-benzoquinoimine (NAPQI) rapidly deplete GSH and covalently modify cellular proteins leading to the generation of high levels of reactive oxygen species (ROS) and depletion of the ATP, which results in mitochondrial damage and hepatocyte and kidney injuries (Hinson et al., 2004). However, it was postulated that depletion of $90 \%$ of GSH in hepatocytes is critically necessary for the development of cell necrosis (Henderson et al., 2000). In addition, hepatic inflammatory cytokines are also reported to be involved in APAP-induced liver injury (Blazka et al., 1996).

Quercetin is a polyphenolic anti-inflammatory and antioxidant compound found in fruits, vegetables, and grains (Burda \& Oleszek, 2001). They have been widely known to have potent cardiovascular protective and therapeutic effects (Chen et al., 2013), scavenging ROS (Xu et al., 2019), antiinflammatory effects (Rogerio et al., 2007), antitumor activities in human leukemia via apoptosis, cell cycle, and autophagy cell signaling (Calgarotto et al., 2018), and liver and kidney protection (Zhang et al., 2017; Yang et al., 2018). Little is known about the effect of quercetin on the protection of kidney 
tissue against acute injury induced by acetaminophen in animal models. Therefore, this study was designed to investigate the degree of nephroprotection by quercetin against APAPinduced acute kidney injury. We also monitored the extent of protection provided by quercetin to known biomarkers of kidney injury such as urea and creatinine.

\section{MATERIAL AND METHOD}

Reagents and assay kits. Quercetin (C15H10O7, CAS Number 117-39-5) was purchased from Sigma-Aldrich (St. Louis, MO, USA) and was prepared daily and freshly by dissolving it in a normal saline solution $(0.9 \% \mathrm{NaCl})$ to the final concentration of $50 \mathrm{mg} / \mathrm{ml}$. Assay kits for determination of malondialdehyde (MDA, Cat No. NWK-MDA01) were purchased from NWLSS (Vancouver, BC, Canada). Glutathione (GSH) assay kit was purchased from Cayman Chemical, Cat. No.703002, MI, USA. ELISA kits for determination the levels of IL-6 (Cat No. ELR-IL6-001) was purchased from RayBio, GA, USA. ELISA kits for determination of TNF-a (Cat No. ab46070) was purchased from Abcam, Cambridge, UK. Urea and creatinine were determined by colorimetric assay using assay kits (ab83362 and ab204537) from Abcam, MA, USA.

Animals. All animal experiments were performed according to the Guide for the Care and Use of Laboratory Animals published by the US National Institutes of Health (NIH publication No. 85-23, revised 1996), and with full approval from King Khalid University Ethical Review Committee (Ethics Statement). Sprague Dawley rats $(n=18)$ weighing $170-200 \mathrm{~g}$ were used in this study. They were housed at a controlled ambient temperature of $25 \pm 2^{\circ} \mathrm{C}$ and $50 \pm 10 \%$ relative humidity, with 12 -h light/12-h dark cycles, and were fed with standard rat's pellets and allowed free access to water.

Experimental design. After a one week adaptation period, rats were randomly assigned into 3 groups $(n=6$; each) and were distributed in their corresponding cages and classified as follows: (1) Control group: rats received normal saline daily for 7 days; (2) APAP intoxicated group (Model group): rats received normal saline for 7 consecutive days and then given a single dose of APAP (2 g/kg, orally) (Galal et al., 2012); and (3) QUR+APAP group: rats were pre-treated with $50 \mathrm{mg} / \mathrm{kg}$ QUR (Murota \& Terao, 2003) for 7 consecutive days and then administered with a single dose of APAP ( $2 \mathrm{~g} /$ $\mathrm{kg}$, orally). APAP was administered to the desired groups one hour after the last dose of treatment on day 7 and all treatment in all groups were administered i.p. in a final volume of $1 \mathrm{ml}$. All animals were sacrificed at day 8 , and kidney tissue and blood were collected for microscopy and blood chemistry analysis.

Determination of blood levels of urea, creatinine, MDA, GSH, TNF-a, and IL-6. At day 8, animals were sacrificed and blood levels of urea, creatinine, MDA, GSH, TNF-a, and IL-6 were determined according to the manufacturer's instructions.

Histological examination. Kidney specimens were immediately fixed in $10 \%$ formal saline for 24 hours. Paraffin blocks were prepared, and $5 \mathrm{~mm}$ thick sections were subjected to hematoxylin and eosin (H\&E) stain to elucidate the status of kidney architecture and the structural changes.

Statistical analysis. The data were expressed as mean \pm standard deviation (SD). Data were processed and analyzed using the SPSS version 10.0 (SPSS, Inc., Chicago, Ill., USA). Oneway ANOVA was done followed by Tukey's post hoc test. Pearson correlation statistical analysis was performed for the detection of a probable significance between two different parameters. Results were considered significant if $\mathrm{p} \leq 0.05$.

\section{RESULTS}

APAP induces acute kidney injury in rats. The disease was induced in the model group of rats by APAP overdose ( $2 \mathrm{~g} / \mathrm{kg}$ body weight), which was confirmed 24 hours post APAP ingestion as demonstrated by a significant $(\mathrm{p}<0.05)$ decline in renal function, and abnormal kidney tissue architecture (Fig. 1). APAP induced nephrotoxicity which caused a sharp increase in blood urea (Fig. 1A) and creatinine (Fig. 1B) compared to normal levels in the control group. H\&E stained images of kidney tissues from the model group revealed numerous renal corpuscles with dilated Bowman's space, tubular dilatation, and congested dilated blood vessels (Fig. 1D) when compared with a normal renal parenchyma in the control group (Fig. 1C).

Quercetin protects kidney tissue architecture against injury induced by APAP. To test the hypothesis that quercetin can protect the architecture of kidney tissues against damage induced by APAP, harvested kidney tissues from all animal groups at day 8 were stained with $H \& E$ and examined under light microscopy. Compared to normal tissue histological structure of Malpighian renal corpuscles (G), proximal (Px) and distal (D) convoluted tubules in the control group (Fig. 2A), APAP substantially damaged the kidney tissue as demonstrated by widening of Bowman's space (arrowhead), vacuolization of tubular epithelium (arrows), dilated convoluted tubules (stars), and desquamation in the 
A
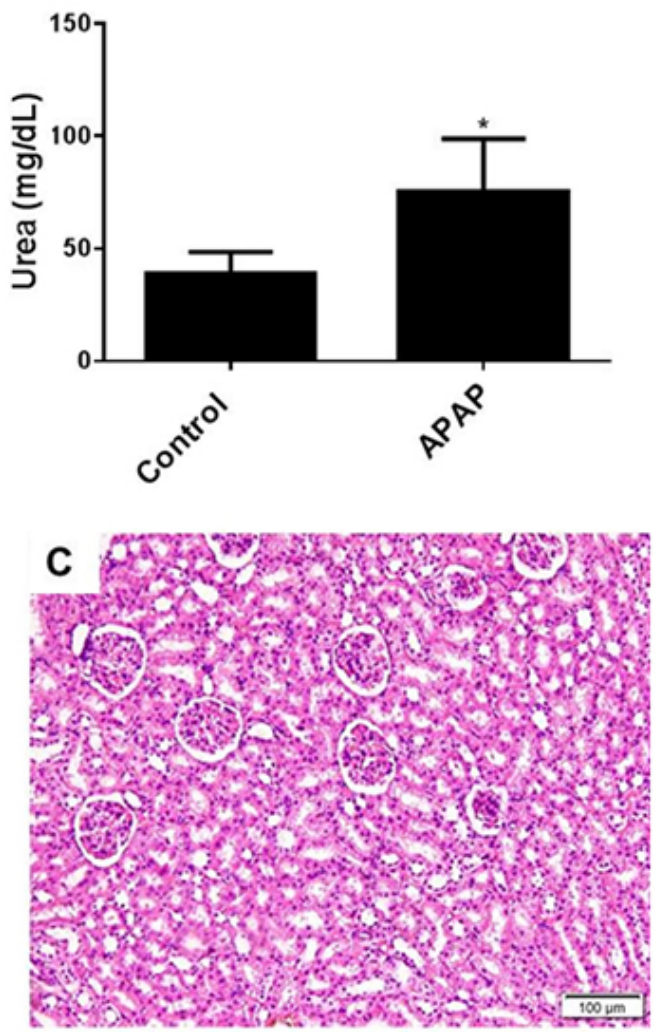

B
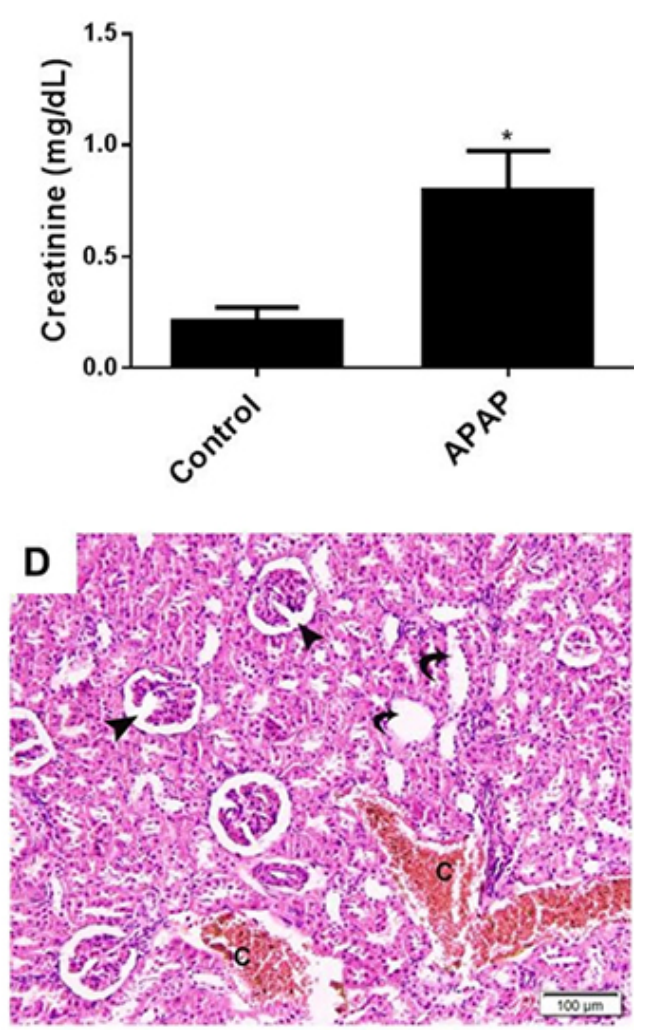

Fig. 1. Induction of acute kidney injury in rats by APAP. Blood levels of urea (A) and creatinine (B) were measured at the end of the experiment in the model group compared to the control group. Results represent the mean $( \pm \mathrm{SD})$, and experiments were performed in triplicate. $* \mathrm{p}<0.05$ versus control. (C and D). H\&E stained images (x100) of harvested tissues obtained from the kidney of model group (D) compared to the control group (C) rats are visualized using light microscopy. Note that arrowheads and curved arrows point to Bowman's space and tubular dilatation, respectively. Abbreviation: $\mathrm{C}$, congested dilated vessels.
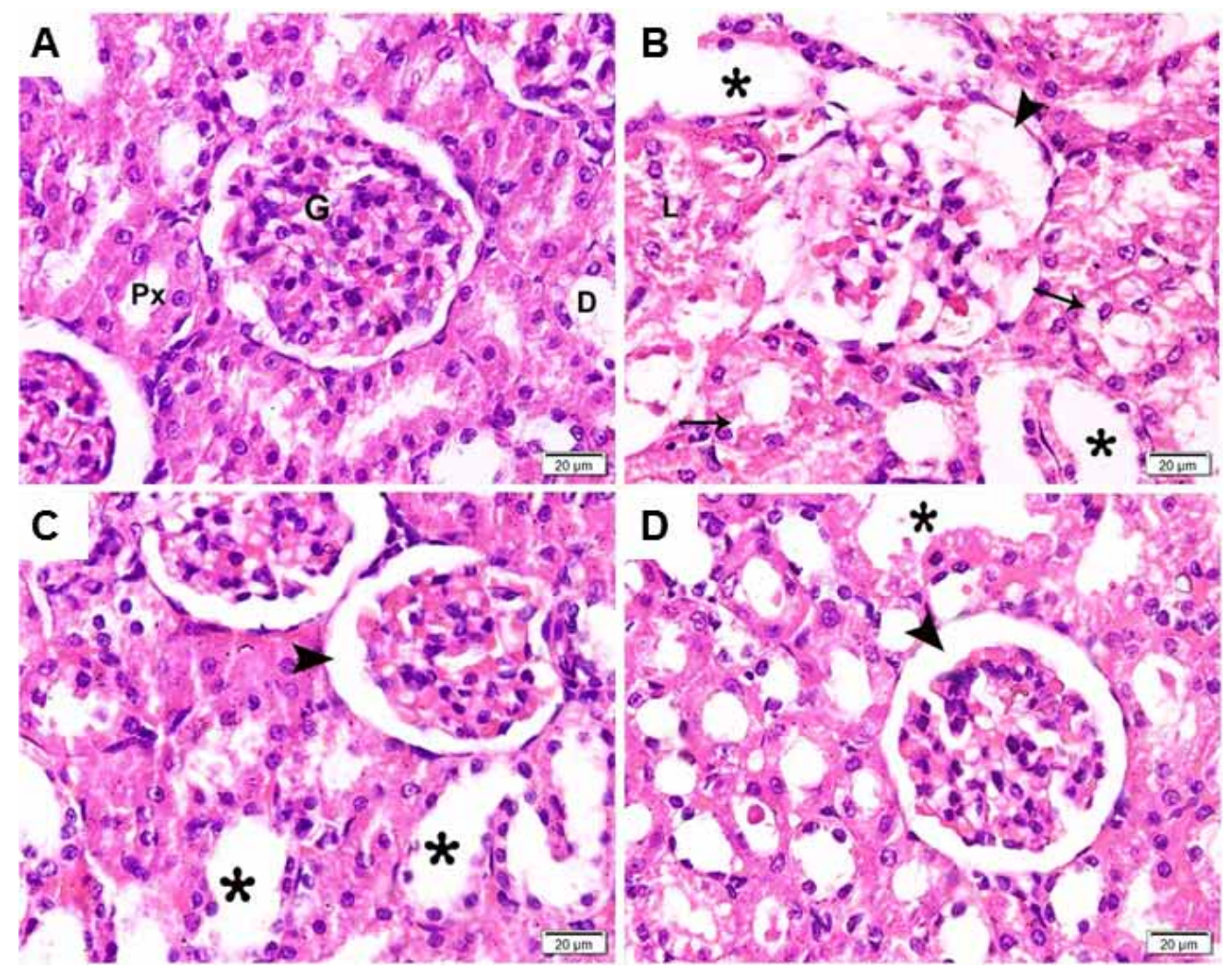

Fig. 2. Quercetin partially protects against APAPinduced acute kidney injury in rats. $\mathrm{H} \& \mathrm{E}$ stained kidney sections ( $\mathrm{x} 400)$ obtained at the end of the experiment in different groups of rats used in this study; Control group (A), APAP group (B), and QUR+APAP group ( $\mathrm{C}$ and D). Note that arrowheads point to the widening of the capsular space, arrows point to vacuolization of tubular epithelium, and stars point to dilated convoluted tubules. Abbreviations: $\mathrm{G}$, Malpighian renal corpuscle; Px, proximal convoluted tubule; D, distal convoluted tubule; $\mathrm{L}$, desquamation in the lumen. 
lumen (L) (Fig. 2B). Pre-treatment with quercetin partially preserved kidney structure of Malpighian renal corpuscles and convoluted tubules (Figs. 2C-D).
A



B

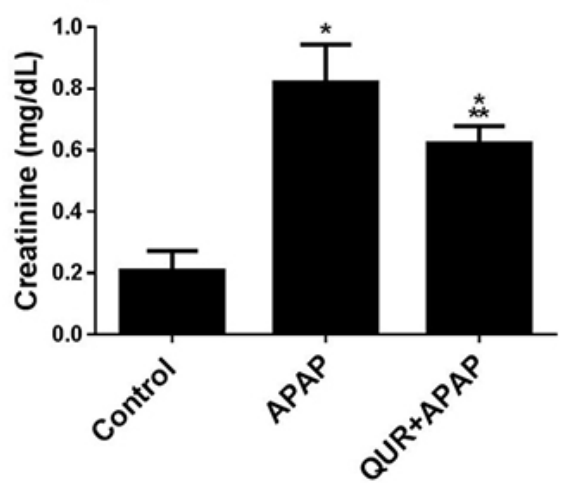

Fig. 3. Quercetin inhibits APAP-induced biomarkers of kidney injury in rats. Blood levels of urea (A) and creatinine (B) were measured at the end of the experiment in different groups of rats used in this study; Control group, APAP group, and QUR+APAP group. Results represent the mean $( \pm S D) ; n=6$ for each group. Experiments were performed in triplicate. $* p<0.05$ versus control, **p<0.05 versus APAP.

A
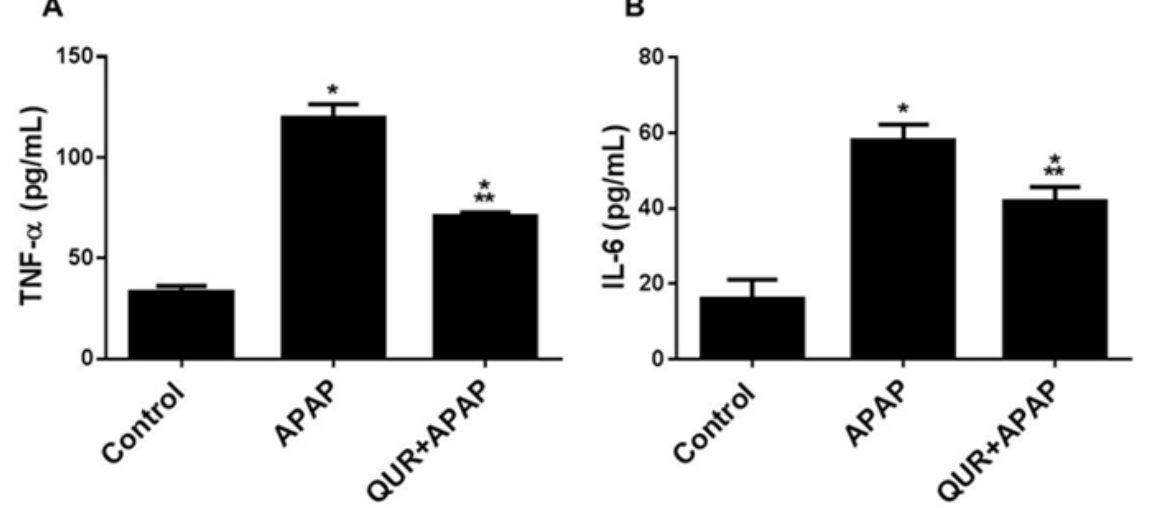

C
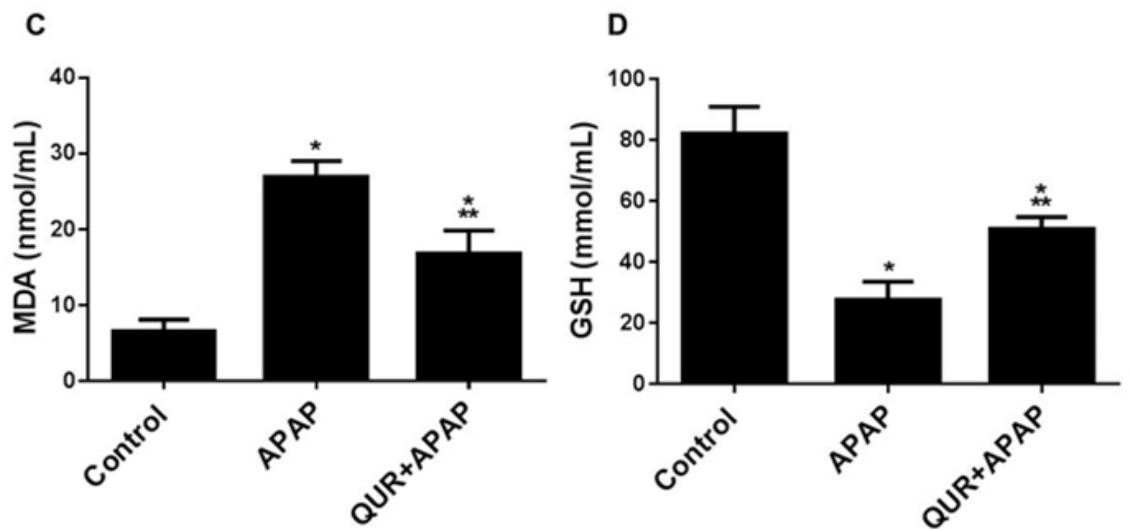

Fig. 4. Quercetin protects against APAP-induced modulation of biomarkers of inflammation, oxidative stress, and antioxidant in rats. Blood levels of TNF-a (A), IL-6 (B), MDA (C), and GSH (D) were measured at the end of the experiment in different groups of rats used in this study; Control group, APAP group, and QUR+APAP group. Results represent the mean $( \pm \mathrm{SD})$; $\mathrm{n}=6$ for each group. Experiments were performed in triplicate. ${ }^{*} \mathrm{p}<0.05$ versus control, $* * \mathrm{p}<0.05$ versus APAP.
Quercetin reduces APAP-induced biomarkers of kidney injury. To investigate whether the observed protection to kidney tissues in the group of rats pre-treated with quercetin shown above was also associated with a reduction in the blood levels of biomarkers of kidney injury, we measured at the end of the experiments blood urea (Fig. 3A) and creatinine (Fig. 3B) in the quercetin-treated group (QUR+APAP) and compared it to the model and control groups. As shown in Figure 3, APAP sharply increased urea and creatinine, which were significantly $(\mathrm{p}<0.05)$ reduced by quercetin. However, the levels of urea and creatinine in the QUR+APAP group were still significant $(\mathrm{p}<0.05)$ to the control group (Figs. 3A-B). This means, a partial inhibition by quercetin was demonstrated.

Quercetin reduces APAP-induced biomarkers of inflammation and oxidative stress. To investigate whether the observed protection to kidney tissues in the group of rats pre-treated with quercetin was also associated with a reduction in the blood levels of biomarkers of inflammation and oxidative stress, we measured at the end of the experiments (day 8) blood TNF-a (Fig. 4A), IL-6 (Fig. 4B), MDA (Fig. 4C), and GSH (Fig. 4D) in the quercetin-treated group (QUR+APAP) and compared it to the model and control groups. Acute kidney injury induced by APAP significantly $(p<0.05)$ increased TNF-a, IL-6, and MDA, which were substantially protected by QUR. In addition, APAP significantly $(p<0.05)$ reduced the antioxidant GSH (Fig. 4D), which were also substantially protected by QUR. However, the levels of these parameters in the QUR+APAP group were still significant $(\mathrm{p}<0.05)$ to the control group (Fig. 4). This means, a partial inhibition by quercetin was seen. 


\section{DISCUSSION}

This article examines the development of acute nephrotoxicity induced by a toxic dose of acetaminophen (APAP) in a rat model of the disease using light microscopy and blood chemistry approaches that demonstrate partial protection by quercetin, which substantially prevents the progression of the disease. In addition, this study links the pathophysiology of acute kidney injury with the elevation of biomarkers of oxidative stress, inflammation, and kidney damage. These conclusions are supported by the data indicating that induction of acute kidney injury using an overdose of the drug APAP caused profound damage to the kidney architecture, which was partially prevented by pretreatment with quercetin for 7 days prior to APAP intoxication (Fig. 2). Furthermore, quercetin significantly decreased circulating biomarkers of oxidative stress (MDA), inflammation (TNF-a and IL-6), and kidney damage (urea and creatinine) (Figs. 3 and 4). Our results were thus consistent with our working hypothesis that the antioxidant and antiinflammatory compound, quercetin, can protect against acute nephrotoxicity induced by APAP overdose in rats.

Elevated levels of biomarkers of oxidative stress, inflammation, and renal dysfunction are documented in many kidney diseases such as chronic kidney disease including patients with end-stage renal failure (Dounousi et al., 2006), uremia (Modaresi et al., 2015; Lahera et al., 2006), acute kidney injury (Bellomo et al., 2012), and renal ischemia and reperfusion injury (Gong et al., 2019). These reports are in agreement with our findings of increased levels of MDA, TNF-a, IL-6, urea, and creatinine (Figs. 3 and 4) in APAP-induced acute kidney injury, and the significant reduction in the levels of these biomarkers upon treatment with quercetin might account for the observed improvement of the kidney histology as indicated by a substantial protection to the tissue architecture (Figs. $2 \mathrm{C}$-D). Indeed, quercetin was reported to improve renal function and protect against adenine-induced chronic kidney disease in rats (Yang et al.), and ameliorates kidney fibrosis in mice with obstructive nephropathy (Ren et al., 2016).

Collectively, our data support the conclusion that quercetin inhibits biomarkers of oxidative stress, inflammation, and renal injury, and partially protects against kidney tissue damage in a rat model of APAP-induced nephrotoxicity.

ACKNOWLEDGEMENTS. This work was supported by the College of Medicine Research Center, Deanship of Scientific Research, King Saud University, Riyadh, Saudi
Arabia. Also, the author would like to thank Professors Bahjat Al-Ani and Mohamed A. Haidara from the Department of Physiology, College of Medicine, King Khalid University, Abha, Saudi Arabia, and Dr. Samaa S. Kamar from the Medical Histology, Kasr Al-Aini Faculty of Medicine, Cairo University, Cairo, Egypt for their input and help during the preparation of this manuscript.

BAYOUMY N. M. La quercetina protege contra la nefrotoxicidad aguda inducida por acetaminofén asociada con la inhibición de biomarcadores de lesión renal aguda en ratas. Int. J. Morphol., 38 (4):876-881, 2020.

RESUMEN: El acetaminofeno (también llamado paracetamol o DCI) causa daño renal agudo después de la ingestión accidental o intencional de una dosis tóxica del medicamento. En el estudio analizamos si el agente antioxidante y antiinflamatorio, la quercetina (QUR) administrada sola, puede proteger contra la nefrotoxicidad aguda inducida por sobredosis de DCI en un modelo de rata. Las ratas recibieron una dosis única de DCI ( $2 \mathrm{~g} / \mathrm{kg}$ ) antes de ser sacrificadas después de 24 horas o fueron pretratadas durante 7 días con QUR (50 mg / kg) antes de recibir una dosis única de DCI y luego sacrificadas 24 horas post ingestión. Los riñones se examinaron mediante microscopía óptica después de la tinción con hematoxilina y eosina (H\&E) y las muestras de sangre recolectadas se analizaron para detectar biomarcadores de estrés oxidativo, inflamación y daño renal. Las secciones de riñón teñidas con H\&E del grupo modelo de ratas (DCI) mostraron un daño sustancial a la arquitectura del riñón, como lo demuestra la ampliación del espacio de Bowman, la dilatación tubular, la vacuolización del epitelio tubular y los vasos sanguíneos dilatados congestionados, que estaban parcialmente protegidos por QUR. Además, DCI aumentó significativamente $(\mathrm{p}<0,05)$ los niveles sanguíneos de la urea, creatinina, malondialdehído (MDA), factor de necrosis tumoral alfa (TNF-a) e interleucina-6 (IL-6), los que fueron reducidos significativamente $(\mathrm{p}<0,05)$ por QUR. Estos resultados indican que la quercetina protege parcialmente contra la lesión renal aguda inducida por DCI en ratas, asociada con la inhibición de biomarcadores de estrés oxidativo, inflamación y lesión renal.

PALABRAS CLAVE: Nefrotoxicidad aguda; Acetaminofeno; Quercetina; Modelo de rata.

\section{REFERENCES}

Bellomo, R.; Kellum, J. A. \& Ronco, C. Acute kidney injury. Lancet, 380(9843):756-66, 2012.

Blazka, M. E.; Elwell, M. R.; Holladay, S. D.; Wilson, R. E. \& Luster, M. I. Histopathology of acetaminophen-induced liver changes: role of interleukin 1 alpha and tumor necrosis factor alpha. Toxicol. Pathol., 24(2):181-9, 1996.

Burda, S. \& Oleszek, W. Antioxidant and antiradical activities of flavonoids. J. Agric. Food Chem., 49(6):2774-9, 2001. 
Calgarotto, A. K.; Maso, V.; Junior, G. C. F.; Nowill, A. E.; Filho, P. L.; Vassallo, J. \& Saad, S. T. O. Antitumor activities of Quercetin and Green Tea in xenografts of human leukemia HL60 cells. Sci. Rep., 8(1):3459, 2018

Chen, Y. W.; Chou, H. C.; Lin, S. T.; Chen, Y. H.; Chang, Y. J.; Chen, L. \& Chan, H. L. Cardioprotective effects of quercetin in cardiomyocyte under ischemia/reperfusion injury. Evid. Based Complement. Alternat. Med., 2013:364519, 2013.

Dounousi, E.; Papavasiliou, E.; Makedou, A.; Ioannou, K.; Katopodis, K. P.; Tselepis, A.; Siamopoulos, K. C. \& Tsakiris, D. Oxidative stress is progressively enhanced with advancing stages of CKD. Am. J. Kidney Dis., 48(5):752-60, 2006.

Galal, R. M.; Zaki, H. F.; Seif El-Nasr, M. M. \& Agha, A. M. Potential protective effect of honey against paracetamol-induced hepatotoxicity. Arch. Iran. Med., 15(11):674-80, 2012.

Gong, D. J.; Wang, L.; Yang, Y. Y.; Zhang, J. J. \& Liu, X. H. Diabetes aggravates renal ischemia and reperfusion injury in rats by exacerbating oxidative stress, inflammation, and apoptosis. Ren. Fail., 41(1):75061, 2019.

Hawton, K.; Simkin, S.; Deeks, J.; Cooper, J.; Johnston, A.; Waters, K.; Arundel, M.; Bernal, W.; Gunson, B.; Hudson, M.; et al. UK legislation on analgesic packs: before and after study of long term effect on poisonings. BMJ, 329(7474):1076, 2004.

Henderson, C. J.; Wolf, C. R.; Kitteringham, N.; Powell, H.; Otto, D. \& Park, B. K. Increased resistance to acetaminophen hepatotoxicity in mice lacking glutathione S-transferase Pi. Proc. Natl. Acad. Sci. U. S. A., 97(23):12741-5, 2000.

Hinson, J. A.; Reid, A. B.; McCullough, S. S. \& James, L. P. Acetaminopheninduced hepatotoxicity: role of metabolic activation, reactive oxygen/ nitrogen species, and mitochondrial permeability transition. Drug Metab. Rev., 36(3-4):805-22, 2004.

James, L. P.; Mayeux, P. R. \& Hinson, J. A. Acetaminophen-induced hepatotoxicity. Drug Metab. Dispos., 31(12):1499-506, 2003.

Karaali, H. F.; Fahmi, R. R. \& Borjac, J. M. Effect of Ocimum basilicum leaves extract on acetaminophen-induced nephrotoxicity in BALB/c mice. J. Complement. Integr. Med., 16(2), 2018.

Lahera, V.; Goicoechea, M.; de Vinuesa, S. G.; Oubiña, P.; Cachofeiro, V.; Gómez-Campderá, F.; Amann, R. \& Luño, J. Oxidative stress in uremia: the role of anemia correction. J. Am. Soc. Nephrol., 17(12 Suppl. 3):S174-7, 2006.

Larson, A. M.; Polson, J.; Fontana, R. J.; Davern, T. J.; Lalani, E.; Hynan, L. S.; Reisch, J. S.; Schiødt, F. V.; Ostapowicz, G.; Shakil, A. O.; et al. Acetaminophen-induced acute liver failure: results of a United States multicenter, prospective study. Hepatology, 42(6):1364-72, 2005.

McGill, M. R.; Sharpe, M. R.; Williams, C. D.; Taha, M.; Curry, S. C. \& Jaeschke, H. The mechanism underlying acetaminophen-induced hepatotoxicity in humans and mice involves mitochondrial damage and nuclear DNA fragmentation. J. Clin. Invest., 122(4):1574-83, 2012.

Modaresi, A.; Nafar, M. \& Sahraei, Z. Oxidative stress in chronic kidney disease. Iran. J. Kidney Dis., 9(3):165-79, 2015.

Murota, K. \& Terao, J. Antioxidative flavonoid quercetin: implication of its intestinal absorption and metabolism. Arch. Biochem. Biophys., 417(1):12-7, 2003.

Ostapowicz, G.; Fontana, R. J.; Schiødt, F. V.; Larson, A.; Davern, T. J.; Han, S. H.; McCashland, T. M.; Shakil, A. O.; Hay, J. E.; Hynan, L.; et al. Results of a prospective study of acute liver failure at 17 tertiary care centers in the United States. Ann. Intern. Med., 137(12):947-54, 2002.

Ren, J.; Li, J.; Liu, X.; Feng, Y.; Gui, Y.; Yang, J.; He, W. \& Dai, C. Quercetin inhibits fibroblast activation and kidney fibrosis involving the suppression of mammalian target of rapamycin and b-catenin signaling. Sci. Rep., 6:23968, 2016.

Rogerio, A. P.; Kanashiro, A.; Fontanari, C.; da Silva, E. V.; LucisanoValim, Y. M.; Soares, E. G. \& Faccioli, L. H. Anti-inflammatory activity of quercetin and isoquercitrin in experimental murine allergic asthma. Inflamm. Res., 56(10):402-8, 2007.
Xu, D.; Hu, M. J.; Wang, Y. Q. \& Cui, Y. L. Antioxidant activities of quercetin and its complexes for medicinal application. Molecules, 24(6):E1123, 2019

Yang, H.; Song, Y.; Liang, Y. N. \& Li, R. Quercetin treatment improves renal function and protects the kidney in a rat model of adenine-induced chronic kidney disease. Med. Sci. Monit., 24:4760-6, 2018.

Zhang, J.; Sheng, Y.; Shi, L.; Zheng, Z.; Chen, M.; Lu, B. \& Ji, L. Quercetin and baicalein suppress monocrotaline-induced hepatic sinusoidal obstruction syndrome in rats. Eur. J. Pharmacol., 795:160-8, 2017.

\section{Corresponding author:}

Nervana M. Bayoumy MD, PhD

College of Medicine

King Saud University

P.O. Box 2925(29)

Riyadh 11461

SAUDI ARABIA

\section{Email: nbayoumy@ksu.edu.sa drnerv@hotmail.com}

Received: 30-10-2019

Accepted: 24-01-2020 